\title{
Down-regulation of SREBP-1c is associated with the development of burned-out NASH
}

Tadanobu Nagaya, ${ }^{1}$ Naoki Tanaka,,${ }^{1,2}$ Takefumi Suzuki, ${ }^{3}$ Kenji Sano, ${ }^{3}$ Akira Horiuchi, ${ }^{4}$ Michiharu Komatsu, ${ }^{1}$ Takero Nakajima, ${ }^{2}$ Tomoko Nishizawa, ${ }^{5}$ Satoru Joshita, ${ }^{1}$ Takeji Umemura, ${ }^{1}$ Tetsuya Ichijo, ${ }^{1}$ Akihiro Matsumoto, ${ }^{1}$ Kaname Yoshizawa, ${ }^{1}$ Jun Nakayama, ${ }^{5}$ Eiji Tanaka, ${ }^{1}$ and Toshifumi Aoyama $^{2}$

${ }^{1}$ Department of Gastroenterology, Shinshu University School of Medicine, ${ }^{2}$ Department of Metabolic Regulation, Shinshu University Graduate School of Medicine, ${ }^{3}$ Department of Laboratory Medicine, Shinshu University Hospital, ${ }^{4}$ Department of Gastroenterology, Showa Inan General Hospital, and ${ }^{5}$ Department of Molecular Pathology, Shinshu University Graduate School of Medicine

Corresponding author: Naoki Tanaka, MD, PhD

Department of Metabolic Regulation, Shinshu University Graduate School of Medicine, Asahi 3-1-1, Matsumoto, 390-8621, Japan

Tel.: +81-263-37-2850

Fax: +81-263-37-3094

E-mail: naopi@shinshu-u.ac.jp

Nagaya $\mathrm{T}$ and Tanaka $\mathrm{N}$ contributed equally to this work.

Keywords: burned-out NASH, SREBP-1c, TNF- $\alpha$ 
Running title: Down-regulation of SREBP-1c with NAFLD progression

Conflicts of interest: none

Abbreviations used in this paper: ACC, acetyl-coenzyme A carboxylase; ALT, alanine aminotransferase; AMPK, adenosine monophosphate-activated protein kinase; ANGPTL4, angiopoietin-like protein 4; AOX, acyl-coenzyme A oxidase; apo, apolipoprotein; AST, aspartate aminotransferase; BMI, body mass index; ChREBP, carbohydrate regulatory element-binding protein; CoA, coenzyme A; CPT, carnitine palmitoyl-coenzyme A transferase; CYP, cytochrome P450; DGAT, diacylglycerol acyltransferase; FA, fatty acid; FABP, fatty acid-binding protein; FAS, fatty acid synthase; FAT, fatty acid translocase; FSP, fat-specific protein; GAPDH, glyceraldehyde-3-phosphate dehydrogenase; $\gamma \mathrm{GT}$, $\gamma$-glutamyltransferase; HBV, hepatitis B virus; HCV, hepatitis C virus; HOMA-IR, homeostasis model assessment for insulin resistance; IL, interleukin; LXR, liver $X$ receptor; MCAD, medium-chain acyl-coenzyme A dehydrogenase; MTP, microsomal triglyceride transfer protein; NAFLD, nonalcoholic fatty liver disease; NAS, NAFLD histological activity score; NASH, nonalcoholic steatohepatitis; PDK, pyruvate dehydrogenase; PGC, peroxisome proliferator-activated receptor- $\gamma$ coactivator; PPAR, peroxisome proliferator-activated receptor; qPCR, quantitative polymerase chain reaction; $R X R$, retinoid $X$ receptor; $S C D$, stearoyl-coenzyme A desaturase; SREBP, sterol regulatory element-binding protein; SS, simple steatosis; TG, triglycerides; TNF, tumor necrosis factor; TNR, TNF receptor; TP, trifunctional protein; US, ultrasonography; VLDL, very-low-density lipoprotein 


\section{Abstract}

Background/Aims: It is well-known that hepatic triglycerides (TG) diminish with the progression of nonalcoholic steatohepatitis (NASH), which has been designated as burned-out $\mathrm{NASH}$, but its mechanism remains unclear. We aimed to explore the changes in hepatic fatty acid (FA) and TG metabolism with disease progression.

Methods: Hepatic expression of key genes in healthy individuals ( $n=6)$ and patients with simple steatosis (SS, $n=10$ ), mild NASH (fibrosis stage $1-2, n=$ 20), and advanced NASH (fibrosis stage $3-4, n=20$ ) were assessed by quantitative polymerase chain reaction.

Results: Hepatic expression of genes related to FA uptake and oxidation and very-low-density lipoprotein synthesis/export did not differ among the groups. However, the mRNA levels of sterol regulatory element-binding protein (SREBP)-1c and its downstream genes FA synthase, acetyl-coenzyme A carboxylase 1, and diacylglycerol acyltransferase 1 were inversely correlated with fibrosis stage. Immunoblot analysis revealed a remarkable reduction in mature SREBP-1c levels in advanced NASH. Furthermore, hepatic expression of tumor necrosis factor- $\alpha$ increased in accordance with fibrosis progression, which was possibly related to the decrease in hepatic SREBP-1c expression.

Conclusion: Down-regulation of SREBP-1c and lipogenic enzymes may be associated with the development of burned-out $\mathrm{NASH}$. 


\section{Introduction}

The prevalence of nonalcoholic fatty liver disease (NAFLD) is increasing worldwide and is estimated to afflict approximately $20 \%$ of the general population in developed countries [1,2]. NAFLD can be divided into simple steatosis (SS) and nonalcoholic steatohepatitis (NASH) by histological findings. $\mathrm{NASH}$ is characterized by the presence of ballooning and lobular inflammation in addition to macrovesicular steatosis [3,4] and may progress to cirrhosis, hepatocellular carcinoma, and ultimately death [4,5]. Lipotoxicity, oxidative stress, pro-inflammatory cytokines, such as tumor necrosis factor (TNF)- $\alpha$, bacterial lipopolysaccarides, and iron accumulation in the liver are presumed to trigger the progression of steatosis to steatohepatitis $[1,6]$.

The hallmark feature of NAFLD/NASH is accumulation of triglycerides (TG) in the liver. Sources of intrahepatic TG include non-esterified fatty acids (FAs) released from adipose tissue and taken up from the blood, as well as those newly synthesized from citrate. FAs are later metabolized mainly by $\beta$-oxidation or by esterification to produce TG, which are either stored in hepatocytes or incorporated into very-low-density lipoprotein (VLDL) particles for export. An imbalance among these metabolic pathways may lead to hepatic steatosis $[1,6]$.

In 1990, Powell et al. first reported a NASH patient who progressed to cirrhosis without hepatic fat deposition in 5 years [7]. Other reports have also demonstrated a significant reduction in hepatic $T G$ accumulation in patients with advanced $\mathrm{NASH}$, which is also designated as burned-out NASH [5,8]. This phenomenon implicates altered hepatic FA/TG metabolism with progression of NAFLD, but its precise molecular mechanism remains unclear. To clarify this, we assessed the hepatic expression of key genes involved in FA/TG metabolism in patients having SS, NASH with mild fibrosis, and NASH with severe fibrosis. 


\section{Patients and Methods}

\subsection{Patients}

Fifty NAFLD patients who underwent a liver biopsy at Shinshu University or its affiliated hospitals between April 2006 and March 2008 were examined. Liver samples included those with SS $(n=10)$, mild NASH (steatohepatitis with fibrosis stage $1-2, n=20$ ), and advanced $\mathrm{NASH}$ (steatohepatitis with fibrosis stage $3-4, n=20)$. NAFLD was suspected by the following criteria: (1) the detection of steatosis by abdominal ultrasonography (US) [9]; (2) the absence of regular intake of alcohol or drugs; (3) negative results for hepatitis B virus (HBV) surface antigen and anti-HBV core and anti-hepatitis C virus (HCV) antibodies; and (4) the absence of other types of chronic liver disease, such as autoimmune liver disease, hereditary hemochromatosis, Wilson's disease, $\alpha 1$-antitrypsin deficiency, and citrin deficiency [10]. The diagnosis of NAFLD was confirmed by liver histology.

The presence of obesity was defined as having a body mass index (BMI) of more than $25 \mathrm{~kg} / \mathrm{m}^{2}$ based on criteria released by the Japan Society for the Study of Obesity. Patients were considered to be hypertensive if their systolic/diastolic pressure was greater than $140 / 90 \mathrm{mmHg}$. Patients were considered to be diabetic if they had a fasting glucose level equal to or higher than $126 \mathrm{mg} / \mathrm{dL}$. Patients were considered to have hyperlipidemia if their fasting serum levels of cholesterol or TG were equal to or higher than 220 or $150 \mathrm{mg} / \mathrm{dL}$, respectively [11].

\subsection{Selection of Normal Controls}

Normal livers were obtained from healthy liver transplantation donors $(n=6)$ at the time of pre-operative percutaneous US-guided liver biopsy who satisfied the 
following criteria: (1) the absence of past history of liver disease and regular intake of alcohol and drugs; (2) the absence of obesity, diabetes, hypertension, and hyperlipidemia; (3) normal liver function tests; and (4) normal liver histology.

\subsection{Laboratory Examination}

Blood samples were obtained at the time of liver biopsy following overnight fasting for 8-10 hours. Laboratory data, such as aspartate and alanine aminotransferase (AST and ALT, respectively) and $\gamma$-glutamyltransferase $(\gamma \mathrm{GT})$, were measured by standard methods using automated analyzers. The homeostasis model assessment for insulin resistance (HOMA-IR) value was calculated as fasting glucose $(\mathrm{mg} / \mathrm{dL}) \times$ immunoreactive insulin $(\mu \mathrm{U} / \mathrm{mL}) / 405$.

\subsection{Histological and Immunohistochemical Analyses}

Percutaneous US-guided liver biopsies were performed as described previously [12]. The average length of the samples was $17.6 \pm 2.8 \mathrm{~mm}$, and the average number of portal tracts found in each sample was $11.8 \pm 3.5$. Fragments of liver tissue $(5-7 \mathrm{~mm})$ were immediately frozen with a RNA stabilization solution (RNAlater ${ }^{\circledR}$ solution, Applied Biosystems, Foster City, CA, USA) in liquid nitrogen and stored at $-80{ }^{\circ} \mathrm{C}$ until RNA extraction. The remaining tissues were fixed in $10 \%$ neutral formalin, embedded in paraffin, cut at $4-\mu \mathrm{m}$ thickness, and stained with the hematoxylin and eosin or Azan-Mallory method. Histological findings were assessed by an independent experienced pathologist (KS) in a blinded fashion and scored according to the staging/grading system proposed by Kleiner et al [13]. The NAFLD histological activity score (NAS) was calculated as the unweighted sum of the scores for steatosis (0-3), lobular inflammation (0-3), and ballooning (0-2). The histological diagnosis of steatohepatitis was made by 
the presence of macrovesicular steatosis, hepatocyte ballooning, and lobular inflammation $[3,4,13]$. Patients with macrovesicular steatosis alone were diagnosed as having SS.

Immunohistochemical staining of sterol regulatory element-binding protein (SREBP)-1c was carried out as described elsewhere [14]. The antibody used in this study (sc-367, Santa Cruz Biotechnology Inc., Santa Cruz, CA, USA) can recognize two SREBP-1 isoforms, SREBP-1c and SREBP-1a. Since the expression of SREBP-1c is predominant in human livers [15,16], the results of this immunohistochemical analysis were regarded to reflect the expression of SREBP-1c. Sections (4 $\mu \mathrm{m}$ thick) were incubated for one hour with the anti-SREBP-1 antibody (1:50 dilution) and immunostained using a Histofine Simple Stain MAX-PO (MULTI) kit with 3,3'-diaminobenzidine as a substrate (Nichirei Biosciences Inc., Tokyo, Japan). The stained sections were viewed with an Olympus DP-70 microscope (Olympus, Tokyo, Japan). The number of SREBP-1c-positive hepatocyte nuclei was counted for each section and expressed as a percentage of all hepatocytes.

\subsection{Analysis of mRNA Expression}

Total RNA was extracted using an RNeasy Mini Kit (QIAGEN, Hilden, Germany) and cDNA was prepared with a Transcriptor First Strand cDNA Synthesis Kit (Roche, Mannheim, Germany). Quantitative polymerase chain reaction (qPCR) was performed using a SYBR Green PCR kit and ABI PRISM 7000 Sequence Detection System (Applied Biosystems, CA, USA). The primer sequences are shown in supplementary Table 1, whose specificity has been confirmed by nucleotide blast (http://blast.ncbi.nlm.nih.gov/Blast.cgi). All mRNA levels were

determined using the $\Delta \Delta \mathrm{Ct}$ method as described previously [17]. The mRNA 
levels of target genes were normalized to those of $18 \mathrm{~S}$ ribosomal RNA and expressed as fold changes relative to those of normal livers.

\subsection{Immunoblot Analysis}

Preparation of whole liver lysates was carried out as described previously [18]. Protein concentration was measured colorimetrically with a $\mathrm{BCA}^{\mathrm{TM}}$ Protein Assay kit (Pierce, Rockford, IL, USA). Whole liver lysates (100 $\mu \mathrm{g}$ of protein) were subjected to $10 \%$ sodium dodecyl sulfate-polyacrylamide gel electrophoresis [19]. Three samples from each group were loaded into each electrophoresis assay and all samples were examined. After electrophoresis, proteins were transferred to nitrocellulose membranes and incubated with primary antibodies (1:200 dilution) against SREBP-1 (sc-367), peroxisome proliferator-activated receptor (PPAR) $\alpha$ (sc-9000), PPAR $\delta$ (sc-7197), PPAR $\gamma$ (sc-7196), or retinoid X receptor $(\mathrm{RXR}) \alpha$ (sc-553), all purchased from Santa Cruz Biotechnology Inc., followed by alkaline phosphatase-conjugated goat anti-rabbit IgG (Jackson ImmunoResearch Laboratories, West Grove, PA, USA). The positions of precursor and mature SREBP-1c bands were determined by molecular weight (125 and $68 \mathrm{kDa}$, respectively). Glyceraldehyde-3-phosphate dehydrogenase (GAPDH) was used as the loading control. Band intensities were measured densitometrically, normalized to those of GAPDH, and subsequently expressed as fold changes relative to those of normal livers.

\subsection{Ethics}

This study was carried out in accordance with the World Medical Association Helsinki Declaration and was approved by each hospital's respective human ethics committee. Informed consent was obtained from all patients. 


\subsection{Statistical Analysis}

Statistical analyses were performed using SPSS software version 11.0 for Windows (SPSS Inc., Chicago, IL, USA). Clinical parameters were expressed as a number (percentage) or mean \pm SEM, and mRNA and protein levels were presented as mean \pm SEM. Comparisons between groups were made using the Kruskal-Wallis test with Bonferroni's correction. Correlation coefficients were calculated using Spearman's rank correlation analysis. All $P$ values were based on a two-sided test for statistical significance. A $P$ value of less than 0.05 was considered to be statistically significant. 


\section{Results}

\subsection{Clinical and Histological Findings}

The clinical and histological findings of 56 participants are summarized in Table 1 and 2, respectively. In 50 NAFLD patients, BMI, serum levels of AST, ALT, and $\gamma$ GT, and HOMA-IR values were significantly greater in the advanced NASH group than in the other groups and increased with disease progression $(r=$ 0.332, $P=0.017$ for BMI; $r=0.664, P<0.001$ for serum AST; $r=0.398, P=$ 0.002 for serum ALT; $r=0.480, P<0.001$ for serum $\gamma \mathrm{GT}$; and $r=0.509, P<$ 0.001 for HOMA-IR), but platelet count and serum albumin concentrations were inversely correlated with fibrosis stage $(r=-0.502, P<0.001$ and $r=-0.421, P=$ 0.008, respectively). Lobular inflammation and ballooning scores were both positively correlated with fibrosis stage $(r=0.495$ and 0.559 , respectively, both $P$ $<0.001)$. The degree of steatosis was the greatest in the mild NASH group, which was significantly different from that in the advanced NASH group $(P=$ 0.008) (Table 2, Fig. 1). Steatosis scores also demonstrated a significant inverse correlation with fibrosis stage $(r=-0.380, P=0.010)$. These results indicate that steatosis decreased with fibrosis progression in our cohort, which is consistent with previous reports $[5,8]$.

\subsection{Hepatic Expression of Genes Associated with FA Oxidation and VLDL Synthesis/Export}

The mRNA levels of genes encoding FA-metabolizing enzymes were measured next, but revealed no differences in the expression of mitochondrial $\beta$-oxidation enzymes [carnitine palmitoyl-coenzyme A (CoA) transferase (CPT) 1, medium-chain acyl-CoA dehydrogenase (MCAD), and trifunctional protein (TP)], peroxisomal $\beta$-oxidation enzyme [acyl-CoA oxidase (AOX)], or microsomal 
w-oxidation enzymes [cytochrome P450 (CYP) 4A11 and CYP2E1] among the groups (Fig. 2A). Similarly, there were no significant differences in the mRNA levels of microsomal TG transfer protein (MTP) or apolipoprotein (apo) B (Fig. 2B). Based on these results, enhancement of FA oxidation and VLDL synthesis/export is not likely to be responsible for attenuation of hepatic steatosis in advanced NASH.

\subsection{Hepatic Expression of Genes Associated with FA Uptake from the}

\section{Blood}

The expression of FA translocase (FAT), FA-binding protein (FABP) 1, and FABP4 was examined, but no significant differences in the mRNA levels of these FA transporters were found (Fig. 2C).

\subsection{Decreased Hepatic Expression of Genes Associated with De Novo}

\section{Lipogenesis in Advanced NASH}

We next assessed the expression of genes that were associated with de novo FA/TG synthesis. The mRNA levels of FA synthase (FAS) were significantly lower in the mild NASH and advanced NASH groups than in the SS group $(P=$ 0.045 and 0.007 , respectively) (Fig. 3). The expression of acetyl-CoA carboxylase (ACC) 1 was also significantly decreased in the advanced NASH group compared with the SS group $(P=0.015)$, as was the expression of diacylglycerol acyltransferase (DGAT) $1(P=0.008)($ Fig. 3). Furthermore, the mRNA levels of these enzymes demonstrated significant inverse correlations with fibrosis stage $(r=-0.427, P<0.001$ for FAS; $r=-0.338, P=0.015$ for ACC1; and $r=-0.367, P=0.010$ for DGAT1). On the other hand, the mRNA levels of other lipogenic enzymes, including ACC2, stearoyl-CoA desaturase 
(SCD), and DGAT2 did not differ among the groups (Fig. 3).

\subsection{Decreased SREBP-1c mRNA Levels in Advanced NASH}

Since the mRNA levels of the above lipogenic enzymes are known to be regulated by SREBP-1c $[6,20]$, its expression was evaluated next. The mRNA levels of SREBP-1c were positively correlated with those of FAS $(r=0.570, P<$ 0.001), ACC1 $(r=0.572, P<0.001)$, and DGAT1 $(r=0.516, P<0.001)$. In addition to meaningful differences between the SS group and mild NASH or advanced NASH group ( $P=0.049$ and 0.010 , respectively) (Fig. 4A), a significant inverse correlation was evident between SREBP-1c mRNA levels and fibrosis stage $(r=-0.392, P=0.009)$. On the other hand, there were no

statistical differences between NAFLD stages in the expression of liver $X$ receptor (LXR) $\alpha$ or PPAR $\gamma$ coactivator (PGC) $1 \beta$, both co-regulators of the SREBP-1c-mediated pathway, or in carbohydrate regulatory element-binding protein (ChREBP) among the groups (Fig. 4A).

\subsection{Decreased Mature SREBP-1c Levels in Advanced NASH}

The activity of SREBP-1c is influenced by several post-transcriptional modification steps, i.e., processing of precursor SREBP-1c proteins (maturation) and translocation of mature SREBP-1c proteins into the nucleus $[6,20]$. To confirm whether mature SREBP-1c levels were also reduced in advanced NASH, immunoblot analysis was performed. Hepatic levels of mature SREBP-1c were significantly increased in the SS group compared with normal controls $(P<$ 0.001 ), but were significantly decreased in the mild and advanced NASH groups compared with the SS group (both $P<0.001$ ) (Fig. 5). Mature SREBP-1c levels were positively correlated with those of FAS $(r=0.403, P=0.004), \operatorname{ACC} 1(r=$ 
0.359, $P=0.014)$, and DGAT1 $(r=0.355, P=0.021)$, and were inversely correlated with fibrosis stage $(r=-0.702, P<0.001)$.

The degree of nuclear translocation of SREBP-1c was also determined by immunohistochemical analysis. Hepatocyte nuclei intensely stained with anti-SREBP-1 antibody were observed preferentially in the SS group, but were extremely rare in the advanced NASH group (black arrowheads in Fig. 6A). Furthermore, although hepatocytes showing cytoplasmic staining for SREBP-1c were detected mainly in both NASH subgroups, their intensity was comparatively weaker in the advanced NASH group (black arrows in Fig. 6A). Lastly, the number of SREBP-1c-positive hepatocyte nuclei was significantly increased in the SS group compared with normal controls $(P<0.001)$, but was significantly decreased in the mild and advanced NASH groups compared with the SS group (both $P<0.001$ ) (Fig. 6B).

Taken together, these results demonstrate that down-regulation of SREBP-1c and its downstream genes is associated with the attenuation of hepatic steatosis in advanced $\mathrm{NASH}$, namely, the development of burned-out NASH.

\subsection{Hepatic Expression of PPARs and RXR $\alpha$}

The expression of PPARs, another group of transcriptional factors involved in hepatic FA/TG metabolism, were also addressed in this study. The mRNA levels of PPAR $\alpha$ were decreased in the mild NASH and advanced NASH groups compared with the SS group ( $P=0.038$ and 0.007 , respectively) (Fig. 4B), and were inversely correlated with the stage of fibrosis $(r=-0.432, P=0.003)$. However, immunoblot analysis revealed no significant differences in PPAR $\alpha$ protein levels among the groups (Fig. 7). Furthermore, the levels of PPAR $\delta$, 
PPAR $\gamma$, and a heterodimeric partner of PPARs, RXR $\alpha$ [21], remained unchanged in GPCR and immunoblot analyses (Fig. 4B and 7). Consistent with the immunoblot results were no meaningful differences in the mRNA levels of the PPAR $\alpha$ target genes CPT1, MCAD, AOX and FABP1 [22-25], the PPAR $\delta / \alpha$ target genes pyruvate dehydrogenase kinase (PDK) 4 and angiopoietin-like protein 4 (ANGPTL4) [26,27], or the PPAR $\gamma$ target genes FABP4 and fat-specific protein 27 (FSP27) [28,29] among the groups (Fig. 2 and Supplementary Fig. 1).

\subsection{Increased Expression of Pro-inflammatory Cytokines in Advanced}

\section{NASH}

The mRNA levels of SREBP-1c are reported to be down-regulated by several pro-inflammatory cytokines [30]. We observed that the expression of TNF- $\alpha$ and its receptors, TNR1 and TNR2, was increased in parallel with fibrosis progression in NAFLD patients $(r=0.442, P=0.008$ for TNF- $\alpha ; r=0.377, P=$ 0.033 for TNR1; and $r=0.383, P=0.037$ for TNR2) (Fig. 8). The mRNA levels of TNF- $\alpha$ and TNR1 were significantly higher in the advanced NASH group than those in the normal group ( $P=0.041$ and 0.026 , respectively). The mRNA levels of interleukin (IL)-1 $\beta$ and its receptor (IL-1R) tended to increase with disease progression, but not significantly (Fig. 8). There was also no statistical difference in hepatic IL-6 mRNA levels among the NAFLD subgroups (Fig. 8). Of these pro-inflammatory cytokines, only the expression of TNF- $\alpha$ showed significant inverse correlations with SREBP-1c mRNA levels $(r=-0.329, P=0.031)$ and mature SREBP-1c levels $(r=-0.396, P=0.041)$, suggesting a possible relationship among NAFLD progression, down-regulation of SREBP-1c, and increased expression of hepatic TNF- $\alpha$. 


\section{Discussion}

A novel and striking finding in this study was the down-regulation of the hepatic SREBP-1c-mediated lipogenic pathway in advanced NASH. Although a close relationship between increased expression of SREBP-1c and hepatic steatosis was shown in rodent models [31,32], there have been few studies to assess hepatic SREBP-1c expression in human livers with NAFLD/NASH. In one report, Higuchi et al. reported an increase in hepatic SREBP-1c mRNA levels in NAFLD patients [33], but they evaluated neither histological findings nor protein levels or intracellular localization of SREBP-1c. Here, we demonstrated by qPCR, immunoblot analysis, and immunohistochemistry that hepatic expression of SREBP-1c is increased in SS, but gradually decreases with fibrosis progression. To our knowledge, this is the first study to explore the changes in hepatic SREBP-1c expression throughout the advancement of NAFLD.

It is conceivable that the down-regulation of SREBP-1c in advanced NASH stems from a reduction in the relative number of hepatocytes, but immunoblot analysis demonstrated a significant reduction in functional SREBP-1c levels with NAFLD progression. Furthermore, the ratio of SREBP-1c-positive hepatocyte nuclei to all hepatocyte nuclei was decreased in advanced $\mathrm{NASH}$, confirming that this possibility is considered to be extremely low.

It is reported that $L X R \alpha, R X R \alpha$, insulin, and pro-inflammatory cytokines, such as TNF- $\alpha$ and IL-1 $\beta$, can modulate the mRNA levels of SREBP-1c [20,30]. However, there were no significant differences in the expression of $\mathrm{LXR} \alpha, \mathrm{RXR} \alpha$, or serum insulin in our cohort. On the other hand, we found that hepatic mRNA levels of TNF- $\alpha$ and its receptors increased with fibrosis progression and were inversely related to those of SREBP-1c. Such a relationship is consistent with the result in a previous study that TNF- $\alpha$ and IL-1, 
but not IL-6, reduced the mRNA levels of SREBP-1c in Hep3B cells [30]. Furthermore in that in vitro experiment, the ability of TNF- $\alpha$ to reduce SREBP-1c mRNA levels was more marked than that of IL-1 [30]. Based on these findings and our own, we can speculate that hepatic overexpression of TNF- $\alpha$ is associated with down-regulation of SREBP-1C and the development of burned-out NASH. Adenosine monophosphate-activated protein kinase (AMPK) is also known to be activated in response to oxidative stress and inhibit de novo lipogenesis through suppressing the transcriptional activity of SREBP-1c [6]. Further study is necessary to investigate the contribution of AMPK activation to the pathogenesis of burned-out NASH.

Although the mRNA levels of PPAR $\alpha$ were lower in the advanced NASH group, PPAR $\alpha$ protein levels and the mRNA levels of CPT1, a typical PPAR $\alpha$ target gene in humans possessing a functional PPAR response element in its promoter region [34], remained unchanged. Such a discrepancy may have stemmed from post-transcriptional PPAR $\alpha$ modifications, such as phosphorylation or stabilization through binding with $\mathrm{RXR} \alpha$ and/or various proteins [21,35-37]. Similarly to the case of PPAR $\alpha$, the protein levels of PPAR $\delta$ and PPAR $\gamma$ and the mRNA levels of their target genes did not vary among the NAFLD subgroups, suggesting a negligible direct contribution of PPARs to the progression of NAFLD.

In conclusion, down-regulation of SREBP-1c and lipogenic enzymes is associated with the development of burned-out NASH. Elucidating the hepatic expression of key genes involved in the development of NAFLD/NASH at every stage of fibrosis may lead to the establishment of novel step-wise therapeutic strategies against NAFLD/NASH. 


\section{Acknowledgments}

We thank Trevor Ralph for his editorial assistance. 


\section{References}

[1] de Alwis NM, Day CP. Non-alcoholic fatty liver disease: the mist gradually clears. J Hepatol 2008;48:S104-112

[2] Falck-Ytter Y, Younossi ZM, Marchesini G, McCullough AJ. Clinical features and natural history of nonalcoholic steatosis syndromes. Semin Liver Dis $2001 ; 21: 17-26$.

[3] Brunt EM, Janney CG, Di Bisceglie AM, Neuschwander-Tetri BA, Bacon BR. Nonalcoholic steatohepatitis: a proposal for grading and staging the histological lesions. Am J Gastroenterol 1999;94:2467-2474.

[4] Matteoni CA, Younossi ZM, Gramlich T, Boparai N, Liu YC, McCullough AJ. Nonalcoholic fatty liver disease: a spectrum of clinical and pathological severity. Gastroenterology 1999;116:1413-1419.

[5] Nagaya T, Tanaka N, Komatsu M, Ichijo T, Sano K, Horiuchi A, et al. Development from simple steatosis to liver cirrhosis and hepatocellular carcinoma: a 27-year follow-up case. Clin J Gastroenterol 2008;1:116-121

[6] Browning JD, Horton JD. Molecular mediators of hepatic steatosis and liver injury. J Clin Invest 2004;114:147-152

[7] Powell EE, Cooksley WG, Hanson R, Searle J, Halliday JW, Powell LW. The natural history of nonalcoholic steatohepatitis: a follow-up study of forty-two patients for up to 21 years. Hepatology 1990;11:74-80.

[8] Caldwell SH, Oelsner DH, lezzoni JC, Hespenheide EE, Battle EH, Driscoll CJ. Cryptogenic cirrhosis: clinical characterization and risk factors for underlying disease. Hepatology 1999;29:664-669.

[9] Tanaka N, Tanaka E, Sheena Y, Komatsu M, Okiyama W, Misawa N, et al. Useful parameters for distinguishing nonalcoholic steatohepatitis with mild steatosis from cryptogenic chronic hepatitis in the Japanese population. Liver 
Int 2006;26:956-963.

[10] Komatsu M, Yazaki M, Tanaka N, Sano K, Hashimoto E, Takei Y, et al. Citrin deficiency as a cause of chronic liver disorder mimicking non-alcoholic fatty liver disease. J Hepatol 2008;49:810-820.

[11] Tanaka N, Nagaya T, Komatsu M, Horiuchi A, Tsuruta G, Shirakawa H, et al. Insulin resistance and hepatitis C virus: a case-control study of non-obese, non-alcoholic and non-steatotic hepatitis virus carriers with persistently normal serum aminotransferase. Liver Int 2008;28:1104-1111.

[12] Tanaka N, Ichijo T, Okiyama W, Mutou H, Misawa N, Matsumoto A, et al. Laparoscopic findings in patients with nonalcoholic steatohepatitis. Liver Int $2006 ; 26: 32-38$

[13] Kleiner DE, Brunt EM, Van Natta M, Behling C, Contos MJ, Cummings OW, et al. Design and validation of a histological scoring system for nonalcoholic fatty liver disease. Hepatology 2005;41:1313-1321.

[14] McPherson S, Jonsson JR, Barrie HD, O'Rourke P, Clouston AD, Powell EE. Investigation of the role of SREBP-1c in the pathogenesis of HCV-related steatosis. J Hepatol 2008;49:1046-1054.

[15] Hua X, Wu J, Goldstein JL, Brown MS, Hobbs HH. Structure of the human gene encoding sterol regulatory element binding protein-1 (SREBF1) and localization of SREBF1 and SREBF2 to chromosomes $17 p 11.2$ and 22q13. Genomics 1995;25:667-673.

[16] Shimomura I, Shimano H, Horton JD, Goldstein JL, Brown MS. Differential expression of exons $1 \mathrm{a}$ and $1 \mathrm{c}$ in mRNAs for sterol regulatory element binding protein-1 in human and mouse organs and cultured cells. J Clin Invest 1997;99:838-845

[17] Livak KJ, Schmittgen TD. Analysis of relative gene expression data using 
real-time quantitative PCR and the $2^{-\Delta \Delta C T}$ method. Methods $2001 ; 25: 402-408$.

[18] Aoyama T, Yamano S, Waxman DJ, Lapenson DP, Meyer UA, Fischer V, et al. Cytochrome P-450 hPCN3, a novel cytochrome P-450 IIIA gene product that is differentially expressed in adult human liver. CDNA and deduced amino acid sequence and distinct specificities of cDNA-expressed hPCN1 and hPCN3 for the metabolism of steroid hormones and cyclosporine. J Biol Chem 1989;264:10388-10395.

[19] Aoyama T, Souri M, Ushikubo S, Kamijo T, Yamaguchi S, Kelley RI, et al. Purification of human very-long-chain acyl-coenzyme A dehydrogenase and characterization of its deficiency in seven patients. $J$ Clin Invest 1995;95:2465-2473.

[20] Ferré P, Foufelle F. SREBP-1c transcription factor and lipid homeostasis: clinical perspective. Horm Res 2007;68:72-82.

[21] Tanaka N, Hora K, Makishima H, Kamijo Y, Kiyosawa K, Gonzalez FJ, et al. In vivo stabilization of nuclear retinoid $X$ receptor $\alpha$ in the presence of peroxisome proliferator-activated receptor $\alpha$. FEBS Lett 2003;543:120-124.

[22] Aoyama T, Peters JM, Iritani N, Nakajima T, Furihata K, Hashimoto T, et al. Altered constitutive expression of fatty acid-metabolizing enzymes in mice lacking the peroxisome proliferator-activated receptor $\alpha$ (PPAR $\alpha$ ). J Biol Chem 1998;273:5678-5684.

[23] Mandard S, Müller M, Kersten S. Peroxisome proliferator-activated receptor $\alpha$ target genes. Cell Mol Life Sci 2004;61:393-416.

[24] Rakhshandehroo M, Hooiveld G, Müller M, Kersten S. Comparative analysis of gene regulation by the transcription factor PPAR $\alpha$ between mouse and human. PLoS One 2009;4:e6796.

[25] Nakajima T, Tanaka N, Kanbe H, Hara A, Kamijo Y, Zhang X, et al. 
Bezafibrate at clinically relevant doses decreases serum/liver triglycerides via down-regulation of sterol regulatory element-binding protein-1c in mice: a novel peroxisome proliferator-activated receptor $\alpha$-independent mechanism. Mol Pharmacol 2009;75:782-792.

[26] Abbot EL, McCornack JG, Reynet C, Hassall DG, Buchan KW, Yeaman SJ. Diverging regulation of pyruvate dehydrogenase kinase isoform gene expression in cultured human muscle cells. FEBS J 2005;272:3004-3014.

[27] Staiger H, Haas C, Machann J, Werner R, Weisser M, Schick F, et al. Muscle-derived angiopoietin-like protein 4 is induced by fatty acids via peroxisome proliferator-activated receptor (PPAR)- $\delta$ and is of metabolic relevance in humans. Diabetes 2009;58:579-589.

[28] Yu S, Matsusue K, Kashireddy P, Cao WQ, Yeldandi V, Yeldandi AV, et al. Adipocyte-specific gene expression and adipogenic steatosis in the mouse liver due to peroxisome proliferator-activated receptor $\gamma 1$ (PPAR $\gamma 1)$ overexpression. J Biol Chem 2003;278:498-505.

[29] Matsusue K, Kusakabe T, Noguchi T, Takiguchi S, Suzuki T, Yamano S, et al. Hepatic steatosis in leptin-deficient mice is promoted by the PPAR $\gamma$ target gene Fsp27. Cell Metab 2008;7:302-311.

[30] Kim MS, Sweeney TR, Shigenaga JK, Chui LG, Moser A, Grunfeld C, et al. Tumor necrosis factor and interleukin 1 decrease $\mathrm{RXR} \alpha, \operatorname{PPAR} \alpha, \operatorname{PPAR} \gamma$, $\mathrm{LXR} \alpha$, and the coactivators SRC-1, PGC-1 $\alpha$, and PGC-1 $\beta$ in liver cells. Metabolism 2007;56:267-279.

[31] Shimomura I, Bashmakov Y, Horton JD. Increased levels of nuclear SREBP-1c associated with fatty livers in two mouse models of diabetes mellitus. J Biol Chem 1999;274:30028-30032.

[32] Yahagi N, Shimano H, Hasty AH, Matsuzaka T, Ide T, Yoshikawa T, et al. 
Absence of sterol regulatory element-binding protein-1 (SREBP-1) ameliorates fatty livers but not obesity or insulin resistance in $L e p^{o b} / L e p^{o b}$ mice. J Biol Chem 2002;277:19353-19357.

[33] Higuchi N, Kato M, Shundo Y, Tajiri H, Tanaka M, Yamashita N, et al. Liver X receptor in cooperation with SREBP-1c is a major lipid synthesis regulator in nonalcoholic fatty liver disease. Hepatol Res 2008;38:1122-1129.

[34] Mascaró C, Acosta E, Ortiz JA, Marrero PF, Hegardt FG, Haro D. Control of human muscle-type carnitine palmitoyltransferase I gene transcription by peroxisome proliferator-activated receptor. J Biol Chem 1998;273:8560-8563.

[35] Burns KA, Vanden Heuvel JP. Modulation of PPAR activity via phosphorylation. Biochim Biophys Acta 2007;1771:952-960.

[36] Tanaka N, Moriya K, Kiyosawa K, Koike K, Aoyama T. Hepatitis C virus core protein induces spontaneous and persistent activation of peroxisome proliferator-activated receptor $\alpha$ in transgenic mice: implications for HCV-associated hepatocarcinogenesis. Int J Cancer 2008;122:124-131.

[37] Tanaka N, Moriya K, Kiyosawa K, Koike K, Gonzalez FJ, Aoyama T. PPAR $\alpha$ activation is essential for HCV core protein-induced hepatic steatosis and hepatocellular carcinoma in mice. J Clin Invest 2008;118:683-694. 
Figure Legends

Figure 1. Representative histological findings of the liver stained with hematoxylin and eosin (upper panels) or the Azan-Mallory method (lower panels)

Original magnification, $\mathrm{x} 100$.

Figure 2. Hepatic mRNA levels of genes involved in FA oxidation (A), VLDL synthesis/export (B), and FA uptake (C)

Samples were obtained from normal livers $(n=6)$ or livers with SS $(n=10)$, mild $\mathrm{NASH}(\mathrm{n}=20)$, or advanced NASH $(n=20)$. Results are expressed as mean \pm SEM.

Figure 3. Hepatic mRNA levels of genes involved in de novo lipogenesis

Samples were obtained from normal livers $(n=6)$ or livers with SS $(n=10)$, mild NASH $(n=20)$, or advanced NASH $(n=20)$. Results are expressed as mean \pm SEM. * $P<0.05 ;{ }^{* *}, P<0.01$.

Figure 4. Hepatic mRNA levels of genes encoding transcription factors associated with SREBP-1c (A) and PPARs (B)

Samples were obtained from normal livers $(n=6)$ or livers with $S S(n=10)$, mild $\mathrm{NASH}(\mathrm{n}=20)$, or advanced NASH $(n=20)$. Results are expressed as mean \pm SEM. * $P<0.05 ;{ }^{* *}, P<0.01$.

Figure 5. Immunoblot analysis of SREBP-1C (A) and quantification of mature SREBP-1c levels (B)

Samples were obtained from normal livers $(n=6)$ or livers with SS $(n=10)$, mild 
NASH $(n=20)$, or advanced NASH $(n=20)$. Three samples from each group were loaded into each electrophoresis assay and all samples were examined. A representative blot is shown in panel $(\mathbf{A})$. The mature form of SREBP-1c is detected as a $68 \mathrm{kDa}$ band. Band intensities of mature SREBP-1c were quantified densitometrically, normalized to those of GAPDH, and subsequently expressed as fold changes relative to those of normal livers. Results are expressed as mean \pm SEM (B). ${ }^{* *}, P<0.01$.

Figure 6. Immunohistochemistry of SREBP-1C (A) and quantification of SREBP-1c-positive hepatocyte nuclei (B)

Samples were obtained from normal livers $(n=6)$ or livers with SS $(n=10)$, mild NASH $(n=20)$, or advanced NASH $(n=20)$. SREBP-1c-positive hepatocyte nuclei (black arrowheads) were frequent in SS livers, but rare in advanced NASH livers. Rather, hepatocytes showing cytoplasmic staining for SREBP-1c (arrows) were detected in NASH livers. Yellow arrowheads indicate SREBP-1c-negative hepatocyte nuclei. The number of SREBP-1c-positive nuclei was counted in each section and expressed as a percentage of all hepatocyte nuclei. Results are expressed as mean \pm SEM. ${ }^{* *}, P<0.01$.

\section{Figure 7. Immunoblot analysis of PPARs and RXR $\alpha$}

The same samples used in Figure 5 were obtained from normal livers $(n=6)$ or livers with SS $(n=10)$, mild NASH $(n=20)$, or advanced NASH $(n=20)$. Three samples from each group were loaded into each electrophoresis assay and all samples were examined. A representative blot is shown in panel $(\mathbf{A})$. Band intensities were quantified densitometrically, normalized to those of GAPDH, and subsequently expressed as fold changes relative to those of normal livers. 
Results are expressed as mean \pm SEM (B).

Figure 8. Hepatic mRNA levels of genes encoding pro-inflammatory cytokines and their receptors

Samples were obtained from normal livers $(n=6)$ or livers with SS $(n=10)$, mild $\mathrm{NASH}(\mathrm{n}=20)$, or advanced NASH $(n=20)$. Results are expressed as mean \pm SEM. * $P<0.05$.

Supplementary Figure 1. Hepatic mRNA levels of PPAR target genes

Samples were obtained from normal livers $(n=6)$ or livers with SS $(n=10)$, mild $\mathrm{NASH}(\mathrm{n}=20)$, or advanced NASH $(n=20)$. Results are expressed as mean \pm SEM. 
Supplementary Table 1. Primer pairs used for qPCR

\begin{tabular}{|c|c|c|}
\hline$\overline{\text { Gene }}$ & $\begin{array}{l}\text { GeneBank Accession } \\
\text { Number }\end{array}$ & Primer Sequence \\
\hline$\overline{\mathrm{ACC} 1}$ & NM_198834 & $\begin{array}{ll}\text { F } & \text { 5'-GATGTGGATGATGGGCTACA-3' } \\
\text { R } & \text { 5'-TGAGGCCTTGATCATTACTGG-3' }\end{array}$ \\
\hline ACC2 & NM_001093 & $\begin{array}{l}\text { F 5'-CAGTTCGCCGACTTCCAT-3' } \\
\text { R 5'-TCTTCCACTCCAGGATGTCA-3' }\end{array}$ \\
\hline Albumin & NM_000477 & $\begin{array}{l}\text { F 5'-CCTTGGTGTTGATTGCCTTTGCTC-3' } \\
\text { R 5'-CATCACATCAACCTCTGGTCTCACC-3' }\end{array}$ \\
\hline AOX & NM_004035 & $\begin{array}{l}\text { F 5'-CAGACAGAGATGGGTCATGG-3' } \\
\text { R 5'-TCCTGGGTTTCAGGGTCATA-3' }\end{array}$ \\
\hline ApoB & NM_000384 & $\begin{array}{ll}\text { F } & \text { 5'-CTGGGAAAACTCCCACAGCAAG-3' } \\
\text { R } & \text { 5'-CCACATTTTGAATCCAGGATGCAG-3' }\end{array}$ \\
\hline ChREBP & NM_032954 & $\begin{array}{l}\text { F 5'-CTGGTGTCTCCCAAGTGGAA-3' } \\
\text { R 5'-CACCGCTGAAGAGGGAGTCAACCA-3' }\end{array}$ \\
\hline CPT1 & NM_001876 & $\begin{array}{l}\text { F 5'-CAATCGGACTCTGGAAACG-3' } \\
\text { R 5'-CCGCTGACCACGTTCTTC-3' }\end{array}$ \\
\hline CYP4A11 & NM_000778 & $\begin{array}{l}\text { F 5'-TGAAGGTGATTCTGGGGAGA-3' } \\
\text { R 5'-CAAGCCGTACCCAATCCAT-3' }\end{array}$ \\
\hline CYP2E1 & NM_000773 & $\begin{array}{ll}\text { F } & \text { 5'-CAAGCCATTTTCCACAGGA-3' } \\
\text { R } & \text { 5'-CAACAAAAGAAAACAACTCCATGC-3' }\end{array}$ \\
\hline DGAT1 & NM_012079 & $\begin{array}{l}\text { F 5'-ACTACCGTGGCATCCTGAAC-3' } \\
\text { R 5'-ATAACCGGGCATTGCTCA-3' }\end{array}$ \\
\hline DGAT2 & NM_032564 & $\begin{array}{l}\text { F 5'-CTCATAGCCGCCTACTCC-3' } \\
\text { R 5'-CTAGAACAGGGCAAGCTGGA-3' }\end{array}$ \\
\hline FABP1 & NM_001443 & $\begin{array}{ll}\text { F } & \text { 5'-TGATCCAAAACGAATTCACG-3' } \\
\text { R } & \text { 5'-TCACCTTCCAACTGAACCACT-3' }\end{array}$ \\
\hline FABP4 & NM_001442 & $\begin{array}{l}\text { F 5'-CCTTTAAAAATACTGAGATTTCCTTCA-3' } \\
\text { R 5'-GGACACCCCCATCTAAGGTT-3' }\end{array}$ \\
\hline FAS & NM_004104 & $\begin{array}{l}\text { F } 5 \text { '-CAGGCACACACGATGGAC-3' } \\
\text { R } \text { 5'-CGGAGTGAATCTGGGTTGAT-3' }\end{array}$ \\
\hline FAT & NM_000072 & $\begin{array}{l}\text { F 5'-AGTCACTGCGACATGATTAATGGT-3' } \\
\text { R 5'-CTGCAATACCTGGCTTTTCTCA-3' }\end{array}$ \\
\hline IL-1 $\beta$ & NM_000576 & $\begin{array}{l}\text { F 5'-AACAGGCTGCTCTGGGATTC-3' } \\
\text { R 5'-TAAGCCTCGTTATCCCATGT-3' }\end{array}$ \\
\hline IL-1R & NM_000877 & $\begin{array}{l}\text { F 5'-TGGTTTGTTCCTGCTAAGGT-3', } \\
\text { R 5'-GATCTGTAATGTCACCGGCC-3' }\end{array}$ \\
\hline IL-6 & NM_006002 & $\begin{array}{l}\text { F 5'-GATGAGTACAAAAGTCCTGATCCA-3' } \\
\text { R 5'-CTGCAGCCACTGGTTCTGT-3' }\end{array}$ \\
\hline LXRa & NM_005693 & $\begin{array}{l}\text { F 5'-CGCACTACATCTGCCACAGT-3' } \\
\text { R 5'-TCAGGCGGATCTGTTCTTCT-3' }\end{array}$ \\
\hline MCAD & NM_000016 & $\begin{array}{l}\text { F 5'-GGAGCCATTGATGTGTGCT-3' } \\
\text { R } 5 \text { '-CTGCTTTGGTCTTTATACCAGCTAC-3' }\end{array}$ \\
\hline MTP & NM_000253 & $\begin{array}{l}\text { F 5'-TGTGGCCTTACTATGGAGGAA-3' } \\
\text { R 5'-AAGGAGCGTAGGTCTTTGCAG-3' }\end{array}$ \\
\hline PGC1 $\beta$ & NM_133263 & $\begin{array}{l}\text { F 5'-CCAAGACCAGCAGCTCCTA-3' } \\
\text { R 5'-CCACTGTCAAGGTCTGCTCA-3' }\end{array}$ \\
\hline PPAR $\alpha$ & NM_005036 & $\begin{array}{l}\text { F 5'-GTGCCAGCAGATTCAGTGTC-3' } \\
\text { R 5'-GCCGAGCTCCAAGCTACTC-3' }\end{array}$ \\
\hline PPAR $\beta$ & NM_006238 & $\begin{array}{l}\text { F 5'-TTCCAGAAGTGCCTGGCACT-3' } \\
\text { R 5'-TGCCACAATGTCTCGATGT-3' }\end{array}$ \\
\hline PPAR $\gamma$ & NM_005037 & $\begin{array}{l}\text { F 5'-GACAGGAAAGACAACAGACAAATC-3' } \\
\text { R 5'-GGGGTGATGTGTTGAACTTG-3' }\end{array}$ \\
\hline $\mathrm{RXR} \alpha$ & NM_002957 & $\begin{array}{l}\text { F 5'-GAGACCTACGTGGAGGCAAA-3' } \\
\text { R 5'-GATGGAGCGGTGGGAGA-3' }\end{array}$ \\
\hline $18 S$ & NR_003286 & $\begin{array}{l}\text { F 5'-ATCCATTGGAGGGCAAGTC-3' } \\
\text { R 5'-GAGCTTTTTAACTGCAGCAACTT-3, }\end{array}$ \\
\hline SCD & NM_005063 & $\begin{array}{l}\text { F 5'-CCTAGAAGCTGAGAAACTGGTGA-3' } \\
\text { R 5'-ACATCATCAGCAAGCCAGGT-3' }\end{array}$ \\
\hline SREBP-1c & NM_004176 & $\begin{array}{l}\text { F } 5 \text { 5'-CGCTCCTCCATCAATGACA-3' } \\
\text { R 5'-TGCGCAAGACAGCAGATTTA-3' }\end{array}$ \\
\hline TNF- $\alpha$ & NM_000594 & $\begin{array}{l}\text { F 5'-CGAGTGACAAGCCTGTAGCC-3' } \\
\text { R 5'-CATACCAGGGCTTGGCCTCA-3' }\end{array}$ \\
\hline TNR1 & NM_001065 & $\begin{array}{l}\text { F 5'-ACCAAGTGCCACAAAGGAAC-3' } \\
\text { R 5'-CTGCAATTGAAGCACTGGAA-3' }\end{array}$ \\
\hline TNR2 & NM_001066 & $\begin{array}{l}\text { F 5'-TTCGCTCTTCCAGTTGGACT-3' } \\
\text { R 5'-CACCAGGGGAAGAATCTGAG-3' }\end{array}$ \\
\hline TP & NM_000182 & $\begin{array}{l}\text { F 5'-GTCTTGCGCCCATGATGT-3' } \\
\text { R 5'-CAGCTTCTTCGGGTCAACTC-3' }\end{array}$ \\
\hline
\end{tabular}

$F$, forward sequence; $R$, reverse sequence. 
Table 1. Clinical features of subjects enrolled in this study

\begin{tabular}{|c|c|c|c|c|}
\hline & $\begin{array}{c}\text { Normal controls } \\
(n=6)\end{array}$ & $\begin{array}{l}\text { Simple steatosis } \\
\quad(n=10)\end{array}$ & $\begin{array}{l}\text { Mild NASH } \\
\quad(n=20)\end{array}$ & $\begin{array}{c}\text { Advanced NASH } \\
(\mathrm{n}=20)\end{array}$ \\
\hline Age (yrs) & $43 \pm 11$ & $41 \pm 16$ & $57 \pm 14$ & $63 \pm 12$ \\
\hline Female & $2(30 \%)$ & $3(33 \%)$ & $12(60 \%)$ & $12(67 \%)$ \\
\hline Obesity & $0(0 \%)$ & $6(67 \%)$ & $12(60 \%)$ & $14(78 \%)$ \\
\hline Type 2 Diabetes & $0(0 \%)$ & $0(0 \%)$ & $4(20 \%)$ & $6(33 \%)$ \\
\hline Hypertension & $0(0 \%)$ & $0(0 \%)$ & $6(30 \%)$ & $12(67 \%)$ \\
\hline Hyperlipidemia & $0(0 \%)$ & $1(11 \%)$ & $8(40 \%)$ & $6(33 \%)$ \\
\hline BMI $\left(\mathrm{kg} / \mathrm{m}^{2}\right)$ & $22.3 \pm 1.6$ & $26.2 \pm 3.4$ & $26.9 \pm 4.3$ & $28.6 \pm 4.7$ \\
\hline Platelet count $\left(\times 10^{3} / \mu \mathrm{L}\right)$ & $221 \pm 40$ & $263 \pm 56$ & $206 \pm 57$ & $169 \pm 62$ \\
\hline C-reactive protein $(\mathrm{mg} / \mathrm{dL})$ & $0.1 \pm 0.1$ & $0.1 \pm 0.1$ & $0.5 \pm 1.0$ & $0.3 \pm 0.4$ \\
\hline Albumin (g/dL) & $4.3 \pm 0.3$ & $4.6 \pm 0.2$ & $4.6 \pm 0.3$ & $4.4 \pm 0.5$ \\
\hline AST $(\mathrm{U} / \mathrm{L})$ & $17 \pm 6$ & $31 \pm 9$ & $62 \pm 33$ & $74 \pm 36$ \\
\hline $\operatorname{ALT}(\mathrm{U} / \mathrm{L})$ & $17 \pm 8$ & $56 \pm 21$ & $96 \pm 71$ & $94 \pm 73$ \\
\hline$\gamma \mathrm{GT}(\mathrm{U} / \mathrm{L})$ & $18 \pm 5$ & $66 \pm 60$ & $71 \pm 44$ & $77 \pm 43$ \\
\hline Total cholesterol (mg/dL) & $164 \pm 17$ & $195 \pm 40$ & $221 \pm 33$ & $193 \pm 38$ \\
\hline Triglycerides (mg/dL) & $81 \pm 35$ & $167 \pm 86$ & $157 \pm 89$ & $139 \pm 73$ \\
\hline HDL-cholesterol (mg/dL) & $52 \pm 12$ & $45 \pm 8$ & $50 \pm 10$ & $53 \pm 16$ \\
\hline LDL-cholesterol (mg/dL) & $108 \pm 25$ & $149 \pm 12$ & $129 \pm 29$ & $109 \pm 23$ \\
\hline Glucose $(\mathrm{mg} / \mathrm{dL})$ & $95 \pm 12$ & $103 \pm 19$ & $118 \pm 36$ & $119 \pm 31$ \\
\hline Glycohemoglobin (\%) & $5.1 \pm 0.7$ & $5.3 \pm 0.6$ & $5.9 \pm 0.9$ & $5.9 \pm 1.2$ \\
\hline Insulin $(\mu \mathrm{U} / \mathrm{mL})$ & $7.9 \pm 10.3$ & $18.3 \pm 11.7$ & $19.6 \pm 17.2$ & $26.1 \pm 11.5$ \\
\hline HOMA-IR & $1.8 \pm 1.3$ & $4.8 \pm 3.2$ & $5.9 \pm 6.2$ & $7.9 \pm 4.2$ \\
\hline Ferritin (ng/mL) & $162 \pm 102$ & $228 \pm 235$ & $177 \pm 118$ & $292 \pm 217$ \\
\hline
\end{tabular}

Results are expressed as a number (percentage) or mean \pm SEM. BMI, body mass index; AST, aspartate aminotransferase; ALT, alanine aminotransferase; $\gamma \mathrm{GT}, \gamma$-glutamyltransferase; HDL; high density lipoprotein; LDL, low density lipoprotein; HOMA-IR, homeostasis model assessment for insulin resistance. 
Table 2. Histological features of the subjects

\begin{tabular}{|c|c|c|c|c|}
\hline & $\begin{array}{c}\text { Normal controls } \\
(n=6)\end{array}$ & $\begin{array}{c}\text { Simple steatosis } \\
(n=10)\end{array}$ & $\begin{array}{l}\text { Mild NASH } \\
(n=20)\end{array}$ & $\begin{array}{c}\text { Advanced NASH } \\
(n=20)\end{array}$ \\
\hline \multicolumn{5}{|l|}{ Steatosis } \\
\hline $\begin{array}{l}0 / 1 / 2 / 3 \\
\text { Percentage }\end{array}$ & $\begin{array}{c}6 / 0 / 0 / 0 \\
0\end{array}$ & $\begin{array}{c}0 / 7 / 3 / 0 \\
23 \pm 11\end{array}$ & $\begin{array}{c}0 / 1 / 10 / 9 \\
35 \pm 16\end{array}$ & $\begin{array}{c}0 / 17 / 3 / 0 \\
16 \pm 14\end{array}$ \\
\hline \multicolumn{5}{|c|}{ Lobular inflammation } \\
\hline $0 / 1 / 2 / 3$ & $6 / 0 / 0 / 0$ & $0 / 9 / 1 / 0$ & $0 / 1 / 14 / 5$ & $0 / 1 / 11 / 8$ \\
\hline \multicolumn{5}{|l|}{ Ballooning } \\
\hline $0 / 1 / 2$ & $6 / 0 / 0$ & $10 / 0 / 0$ & $0 / 17 / 3$ & $0 / 13 / 7$ \\
\hline \multicolumn{5}{|l|}{ Fibrosis } \\
\hline $0 / 1 / 2 / 3 / 4$ & $6 / 0 / 0 / 0 / 0$ & $10 / 0 / 0 / 0 / 0$ & $0 / 11 / 9 / 0 / 0$ & $0 / 0 / 0 / 12 / 8$ \\
\hline NAS & 0 & $2.3 \pm 0.5$ & $5.8 \pm 1.0$ & $5.4 \pm 1.0$ \\
\hline
\end{tabular}

Fifty biopsy-proven NAFLD patients were classified as having simple steatosis, mild NASH (fibrosis stage 1-2), or advanced NASH (fibrosis stage 3-4). Results are expressed as a number or mean \pm SEM. NAS, NAFLD activity score. 
Figure 1.

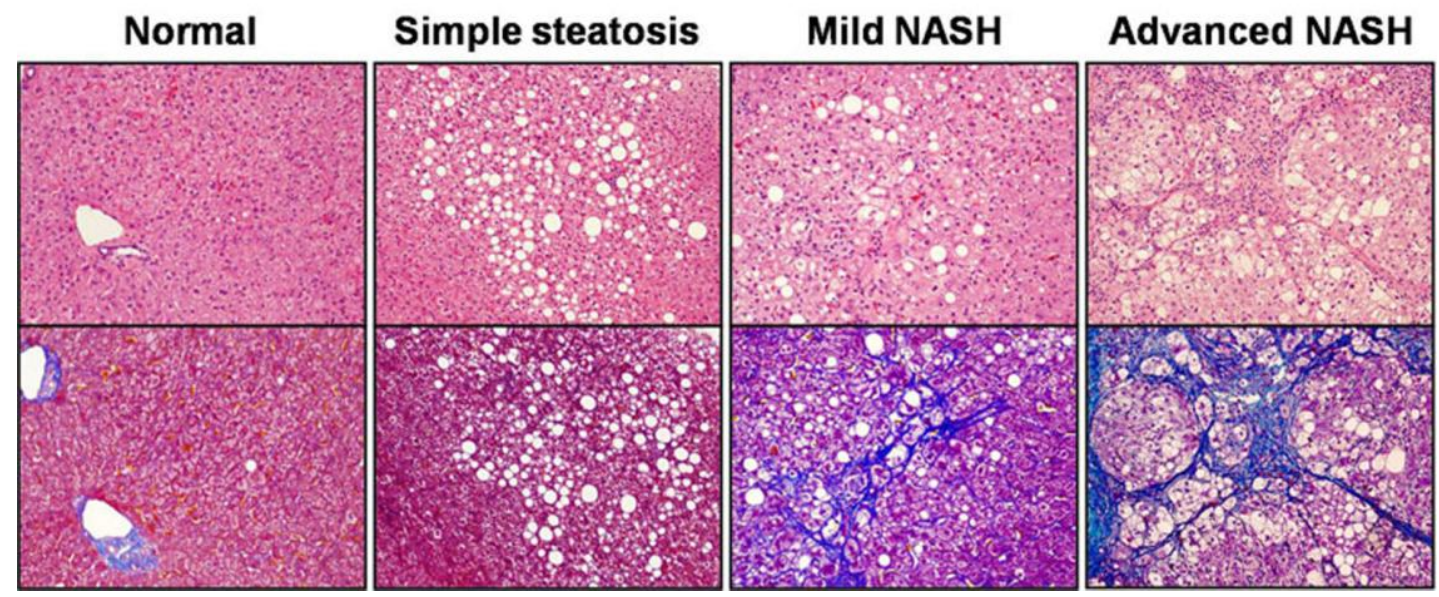


Figure 2.

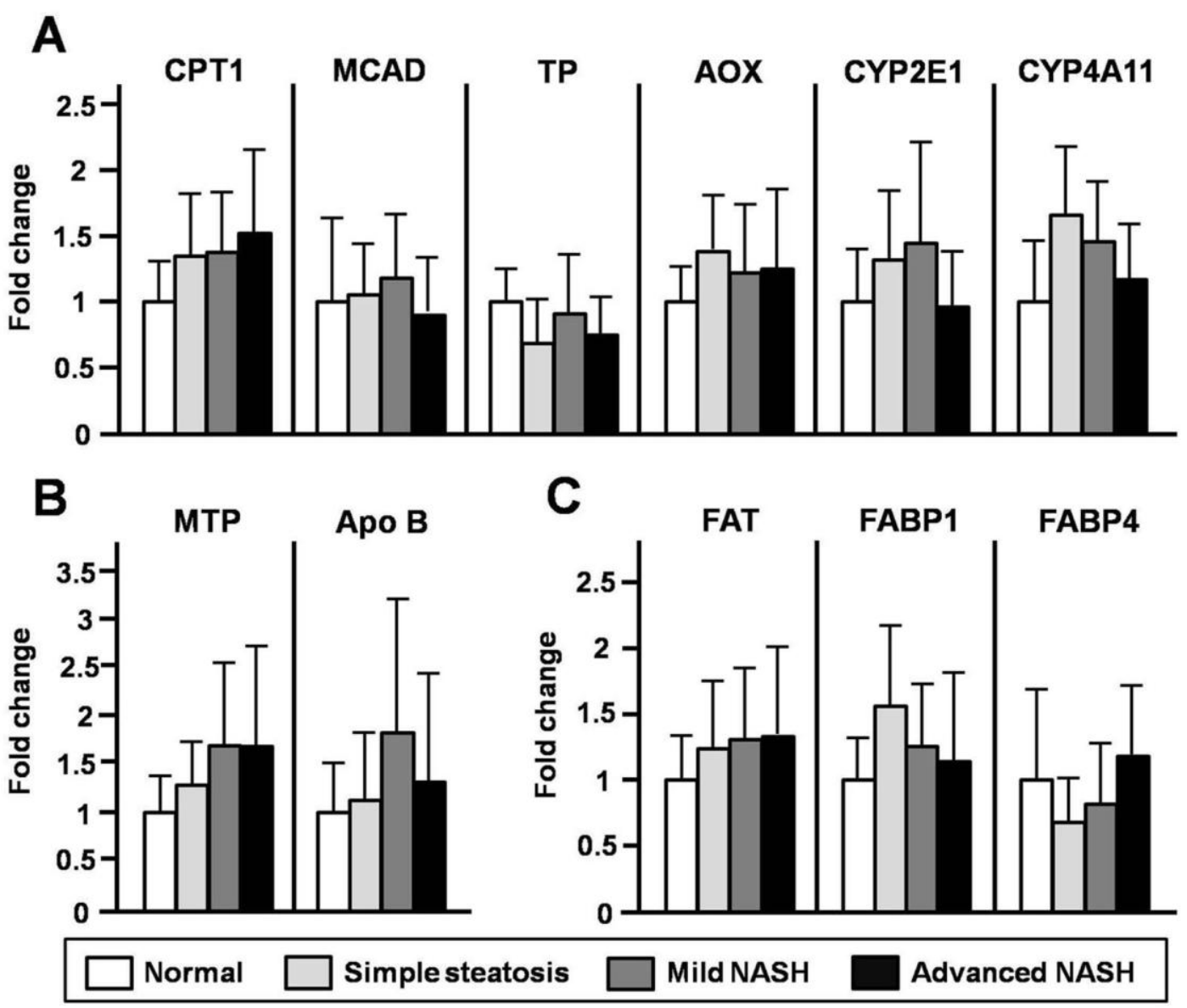


Figure 3.

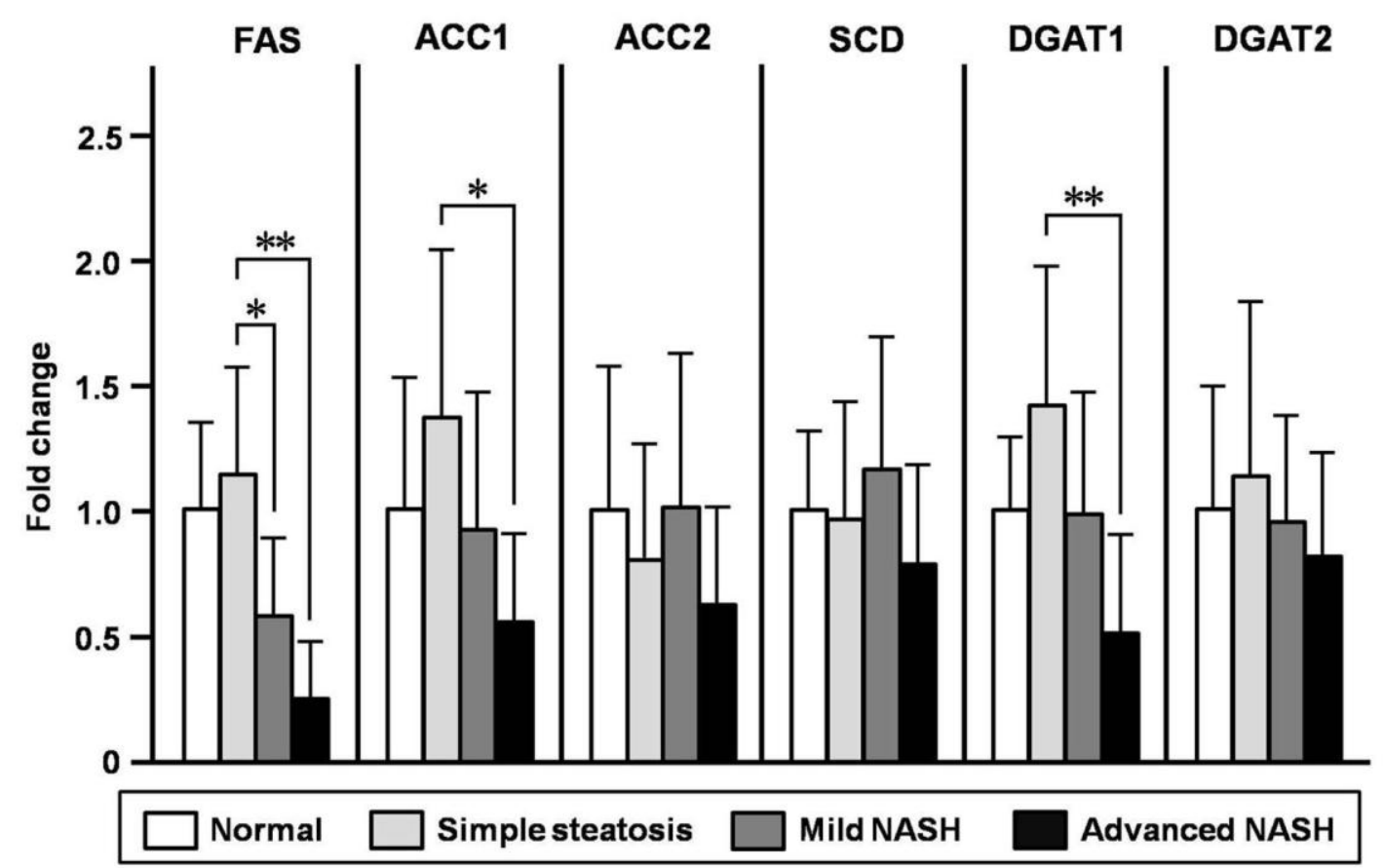


Figure 4.

A SREBP-1C LXR $\alpha$ PGC1 $\beta$ ChREBP

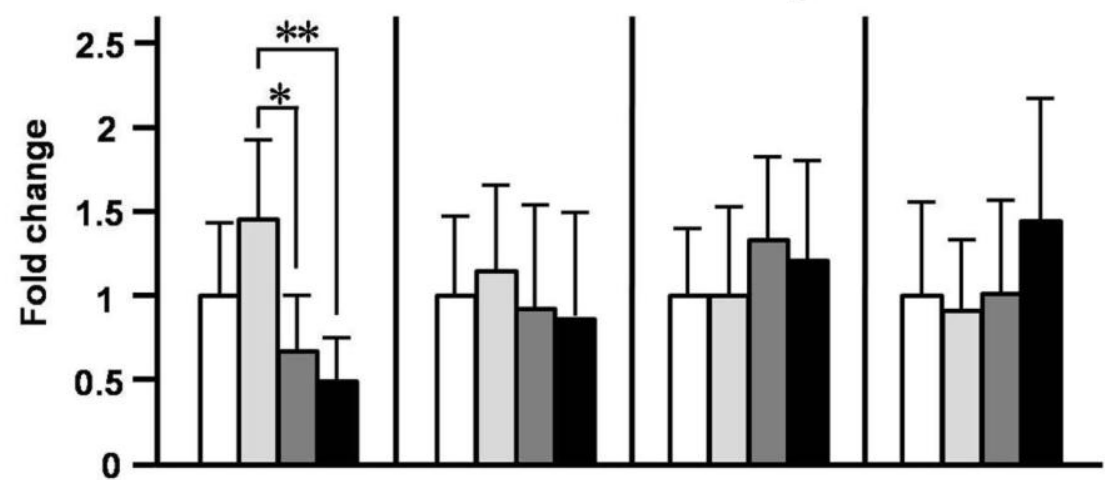

B PPAR $\quad$ PPAR $\quad$ PPAR $\gamma \quad$ RXR

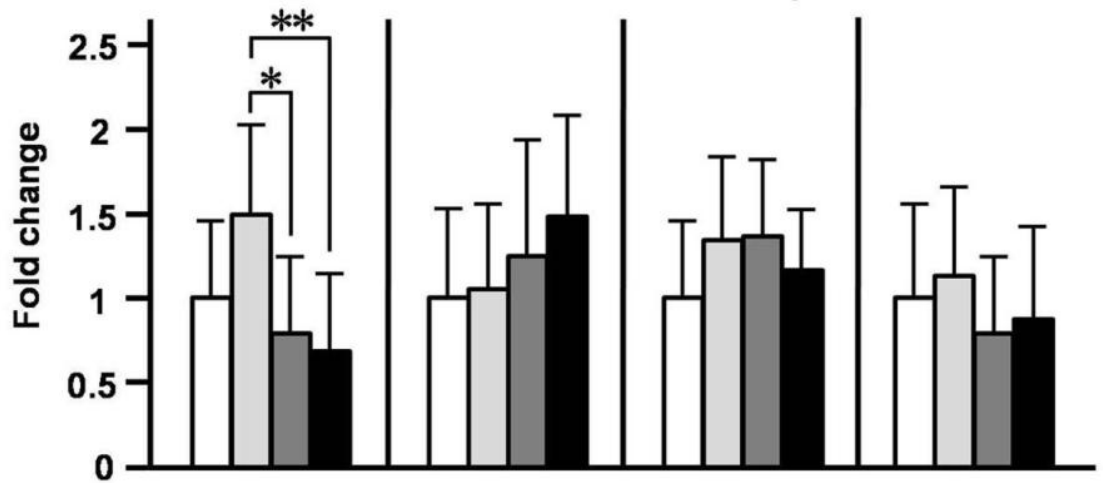

$\square$ Normal $\square$ Simple steatosis $\square$ Mild NASH $\square$ Advanced NASH 
Figure 5.

A

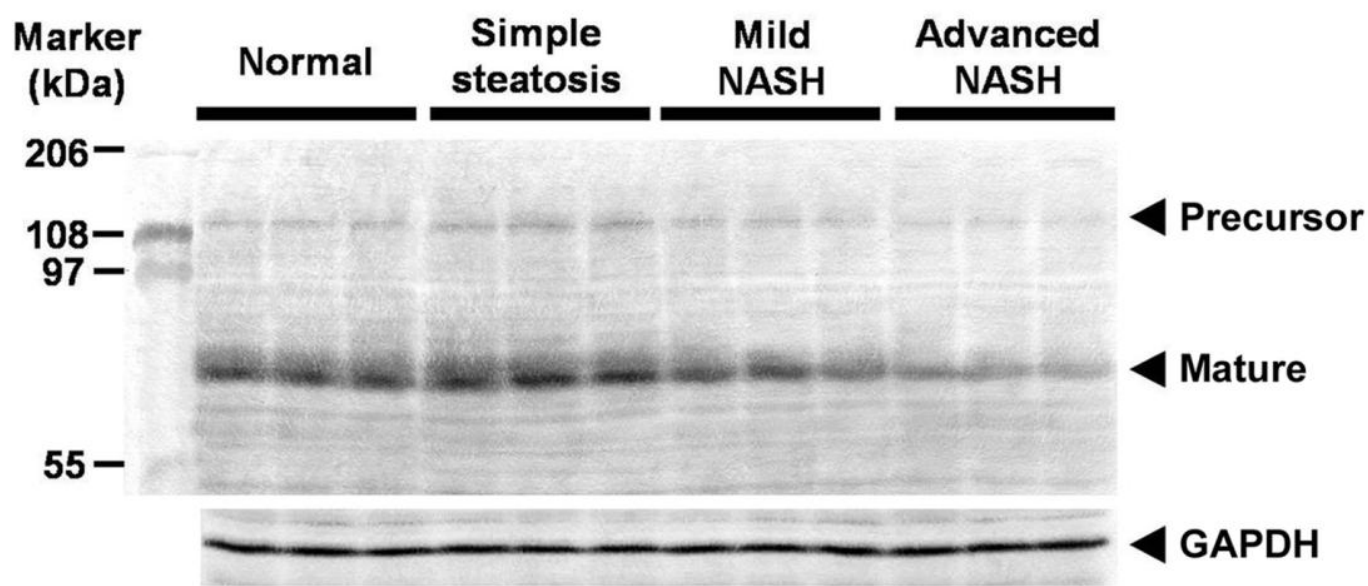

B

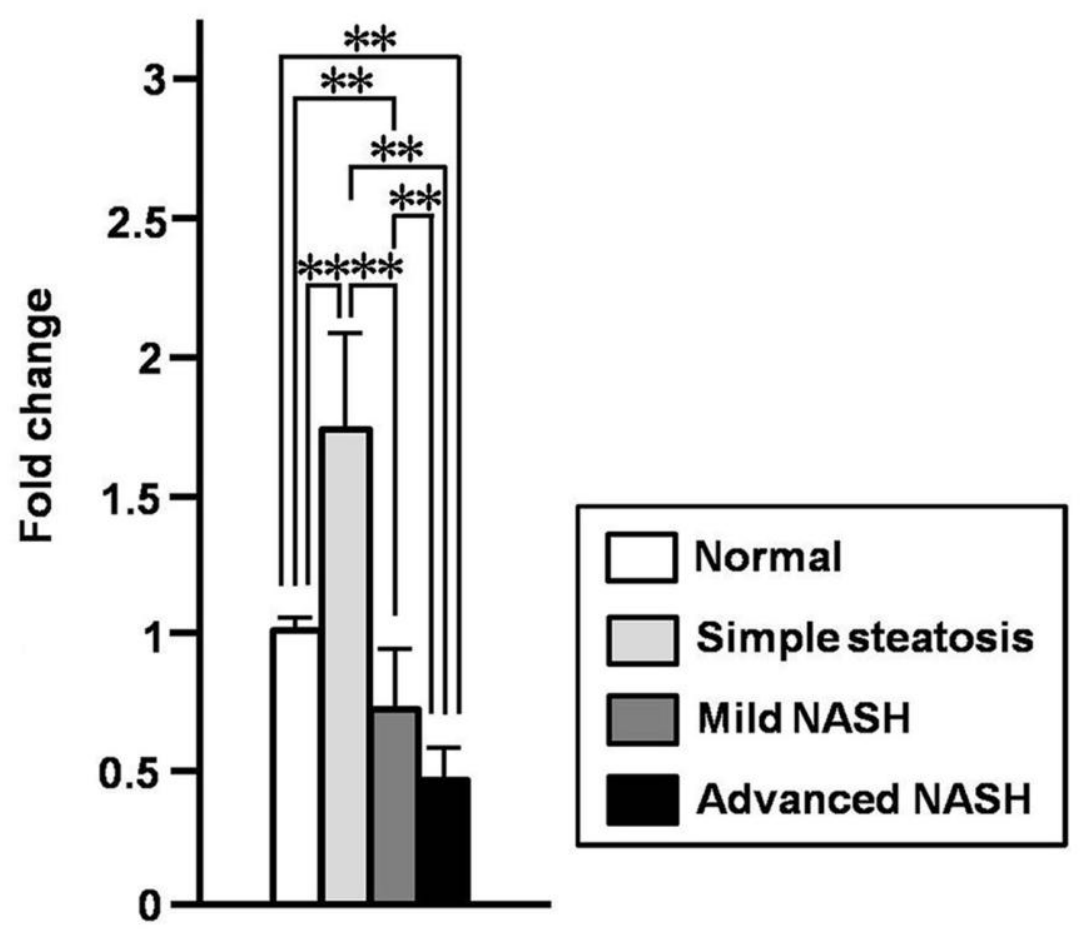


Figure 6.
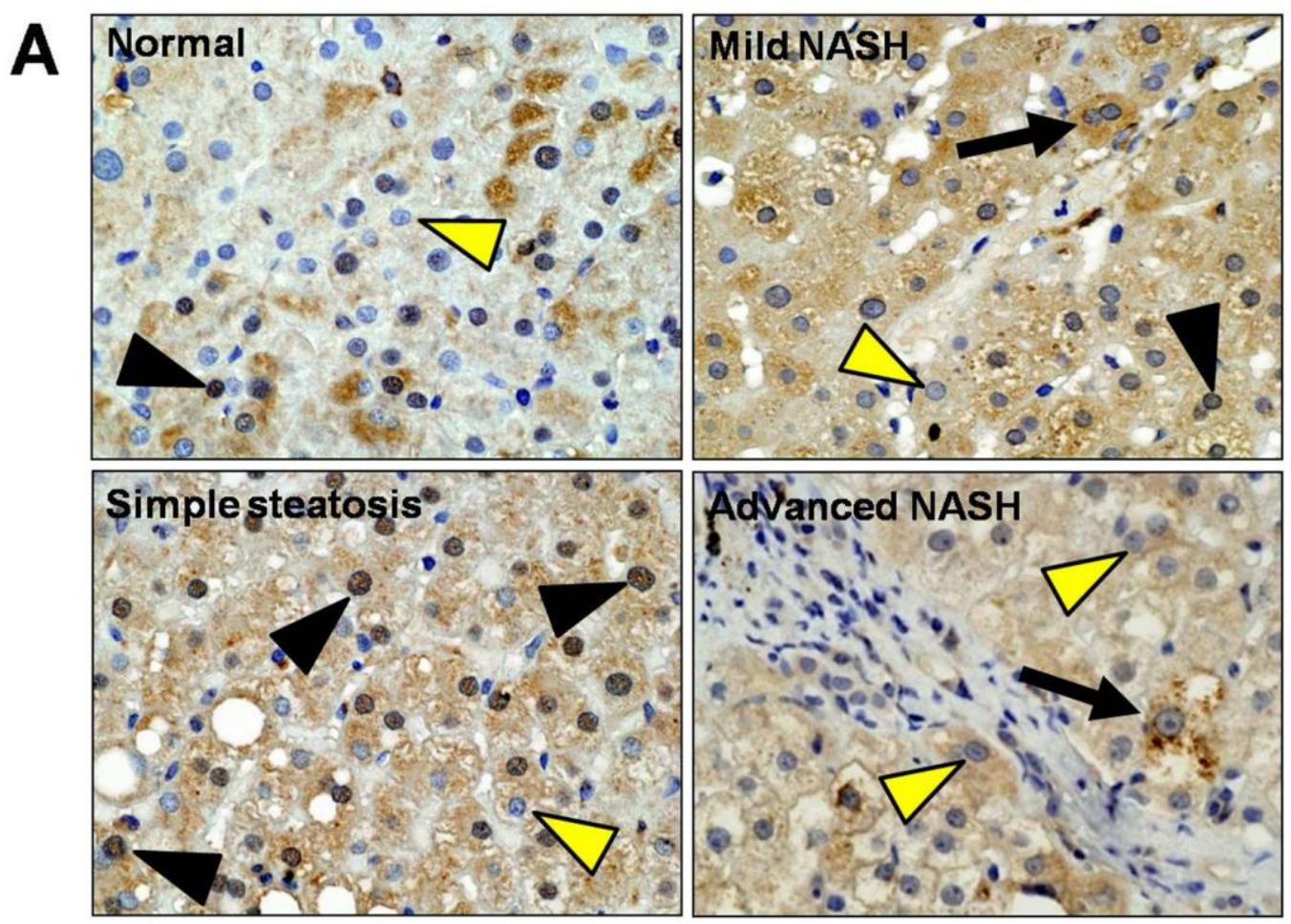

B

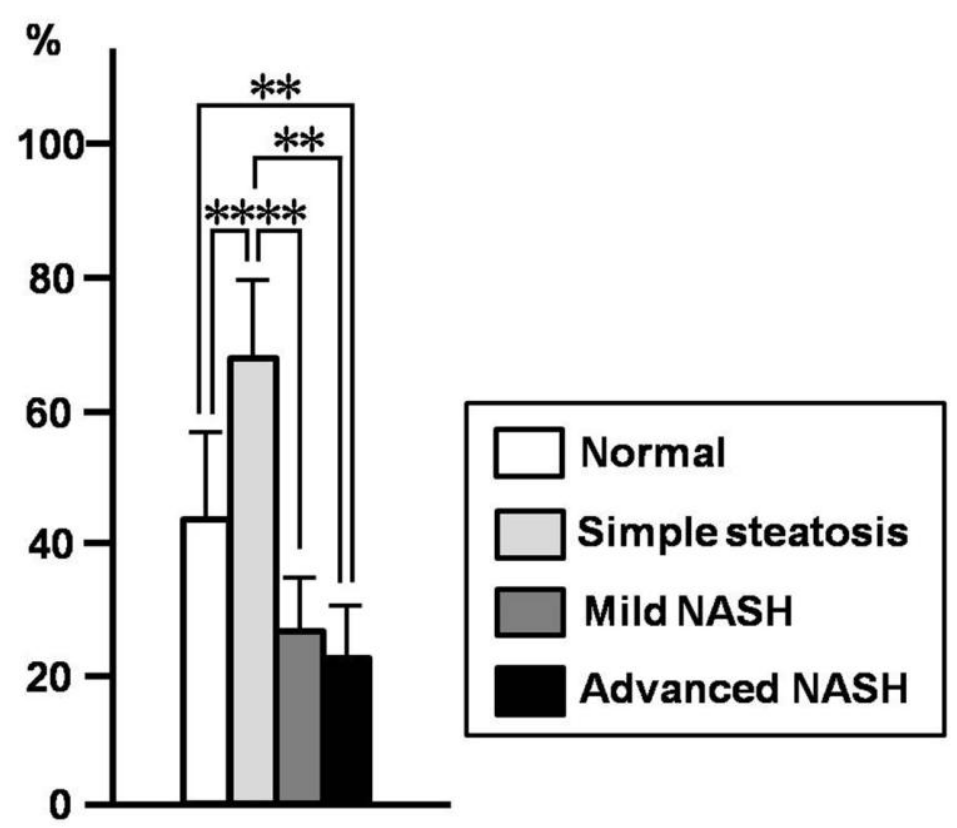


Figure 7.
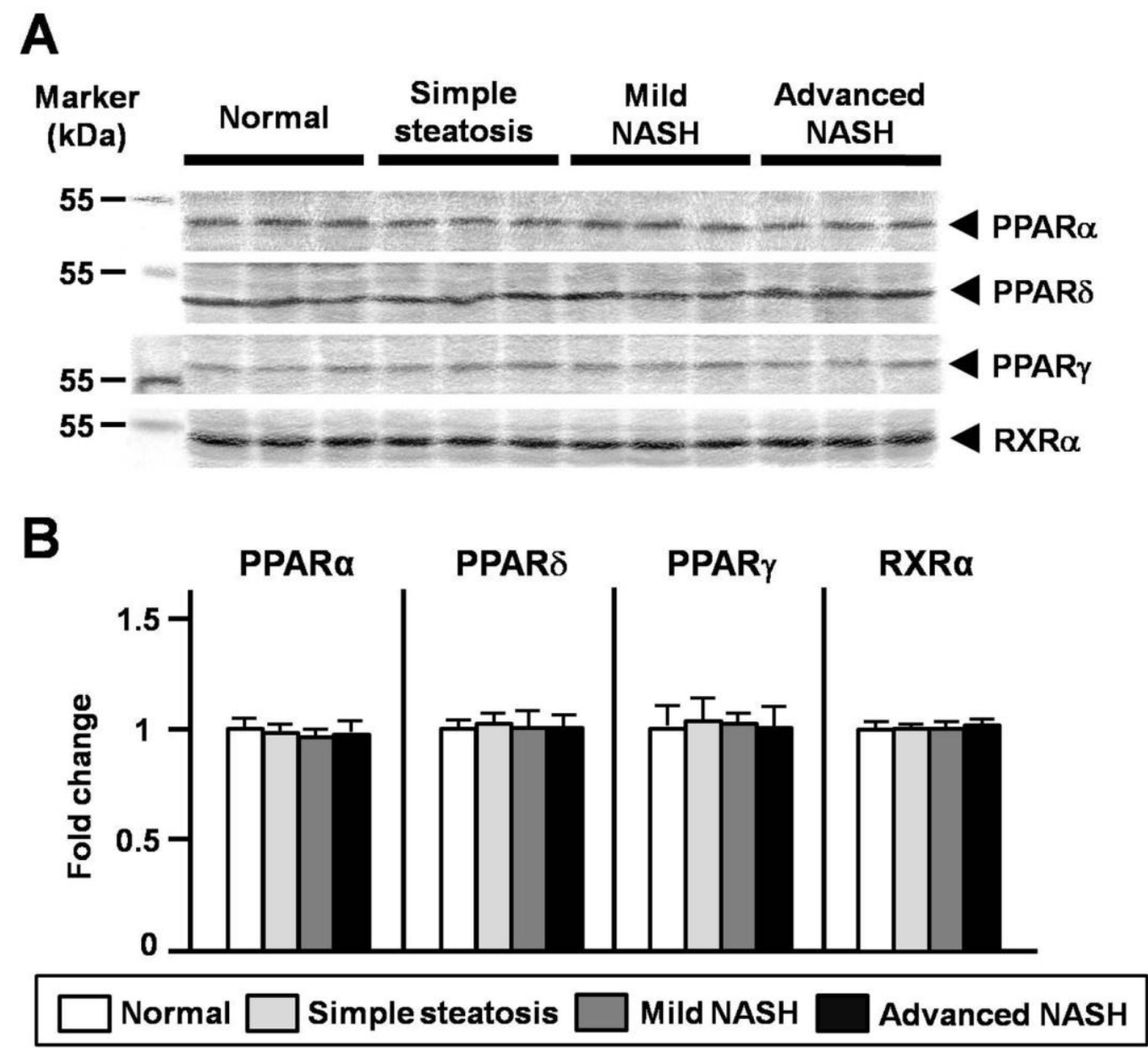
Figure 8.

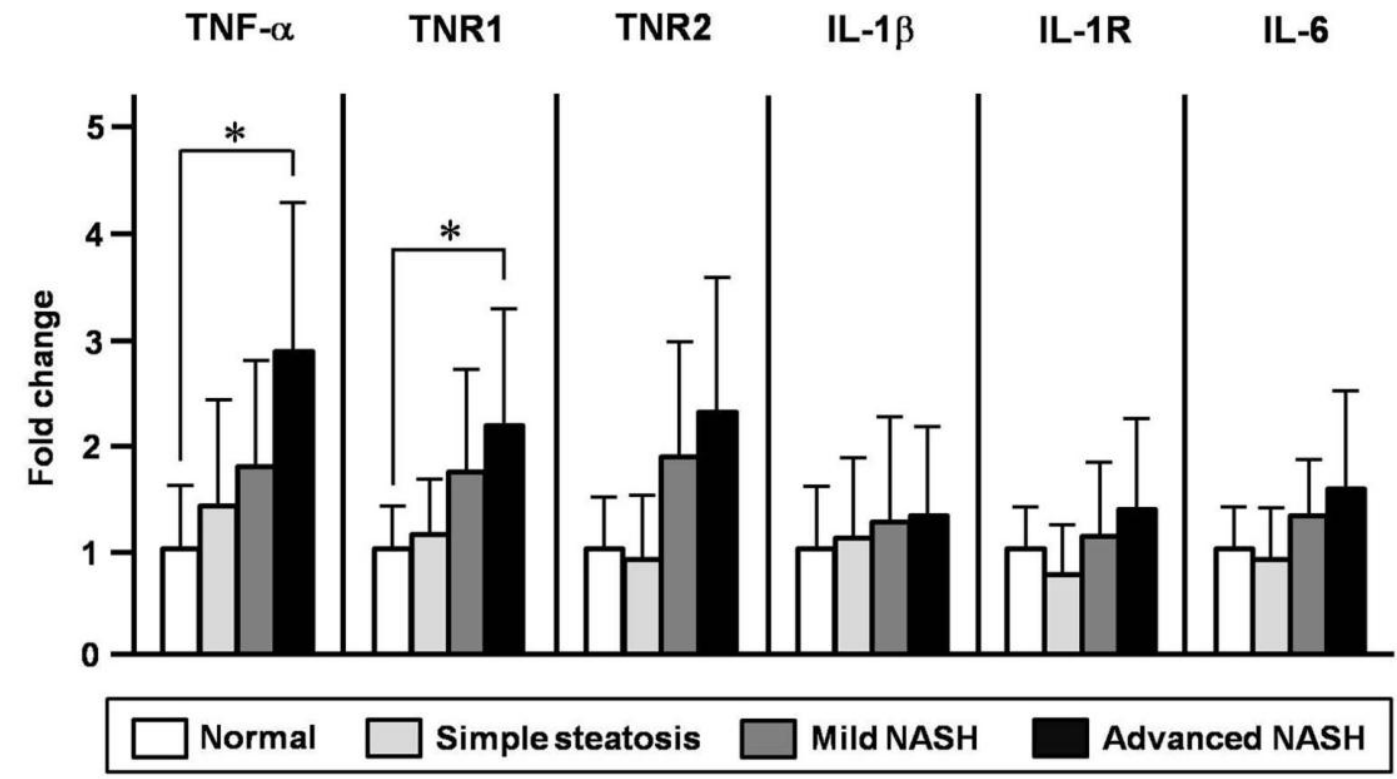


Supplementary Figure 1.

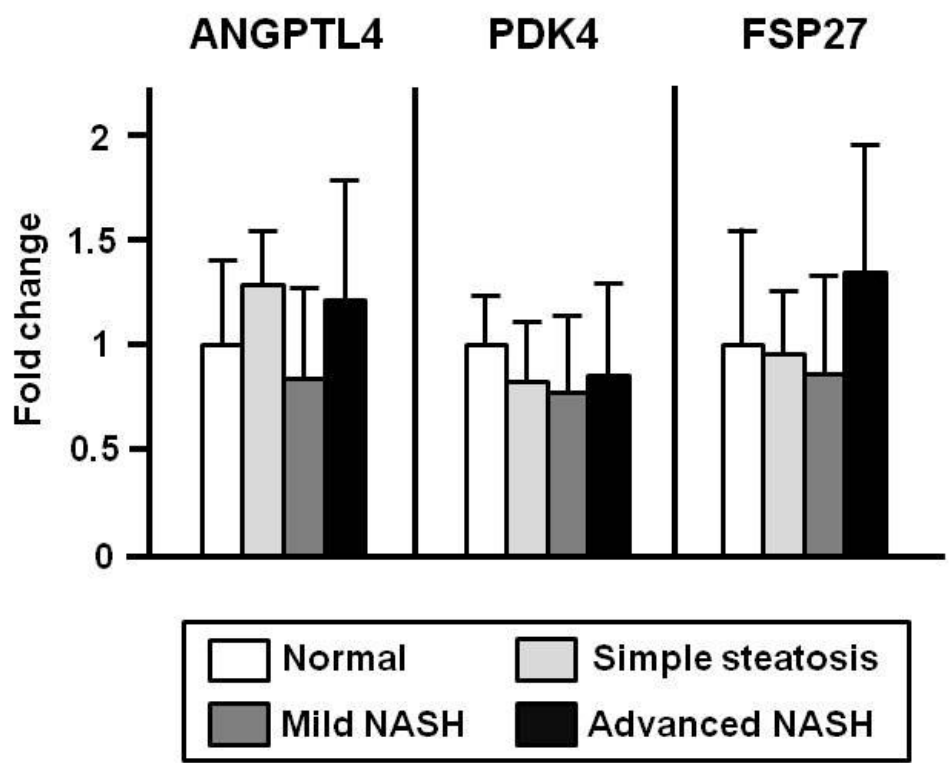

